
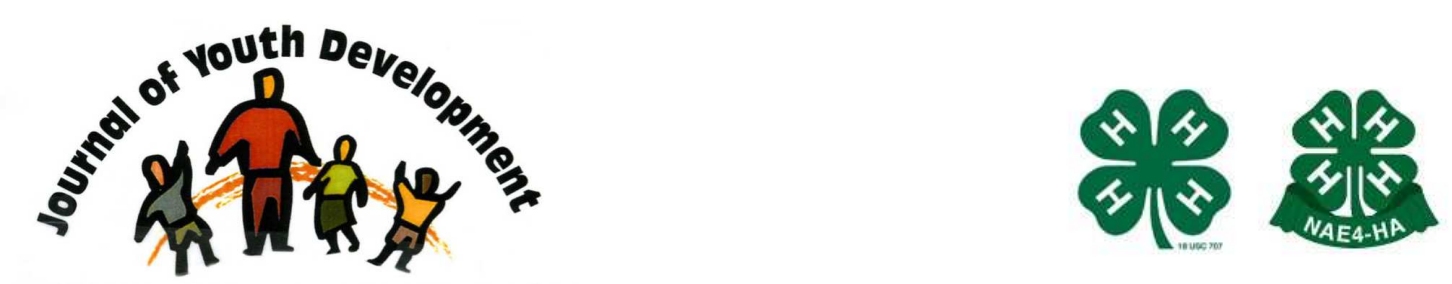

Bridging Research \& Practice

\title{
A Longitudinal Examination of the Relationship Between Media Use and Self-Competence During Adolescence
}

Christine McCauley Ohannessian

Connecticut Children's Medical Center

University of Connecticut School of Medicine 


\title{
JOURNAL OF YOUTH DEVELOPMENT \\ bridging research and practice

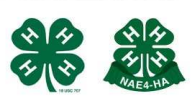

Volume 9, Number 1, Special Edition 2014

Article 140901FA010

\section{A Longitudinal Examination of the Relationship Between Media Use and Self-Competence During Adolescence}

\author{
Christine McCauley Ohannessian \\ Connecticut Children's Medical Center \\ University of Connecticut School of Medicine
}

\begin{abstract}
The primary goal of this longitudinal study was to examine whether media use predicts adolescent self-competence and/or whether adolescent self-competence predicts media use. The sample included $1,03110^{\text {th }}$ and $11^{\text {th }}$ grade boys and girls from the United States. The adolescents completed a self-report questionnaire in 2007 and 2008 to assess their media use (talking and texting on the phone, listening to music, e-mailing/IMing, playing video games, and working on the computer) and selfcompetence (social competence, scholastic competence, athletic competence, and perceived physical appearance). Path analysis results revealed that media use had a minimal effect on adolescent self-competence. In contrast, adolescent self-competence consistently predicted media use. Results from this study highlight the need to examine both directions of influence between adolescent media use and adjustment.
\end{abstract}

\section{Introduction}

Current theories of human development (e.g., developmental systems theory; Lerner et al., 2011) purport that the individual and the context influence one another in order to produce development. One context that is becoming increasingly salient in the lives of adolescents is the world of media that surrounds them. Recent research indicates that adolescents are engaged in media use more than 7.5 hours a day (Rideout, Foehr, \& Roberts, 2010). Moreover, approximately $25 \%$ of the time that adolescents are engaged in media is spent using multiple forms of media simultaneously or "media multi-tasking" (Brown, \& Bobkowski, 2011). Because the use of media has become so central to the daily lives of adolescents, it is imperative that the manner in which this context is related to adolescent development be examined. 
There is a growing literature that suggests that media use may negatively influence adolescents. For example, playing video games has been found to be related to aggressive behavior (Anderson, Gentile, \& Buckley, 2007; Gentile, Lynch, Linder, \& Walsh, 2004). Playing video games, computer games, watching television, and talking on the phone also have been negatively associated with academic performance (Durkin, \& Barber, 2002; Gentile, et al., 2004). In addition, time spent watching television and playing video games has been linked to physical inactivity, weight, and body fat during adolescence (Koezuka, Koo, Allison, Adlaf, Dwyer, Faulkner, \& Goodman, 2006; Marshall, Biddle, Gorely, Cameron, \& Murdey, 2004). The use of the Internet has been found to be related to adolescent psychological problems (loneliness, depression, anxiety) as well (Kraut, Patterson, Lundmark, Kiesler, Mukopadhyay, \& Scherlis, 1998) and recent research indicates that more frequent media use (watching television, text messaging, and e-mailing) is associated with earlier and heavier substance use during adolescence (Ohannessian, 2009).

Relatively few studies have focused on positive effects that media use may have on adolescents. However, results from some investigations suggest that the influence of media on adolescents may not be uniformly negative. In a novel study conducted by Durkin and Barber (2002), both negative and positive correlates of computer game playing were examined in 10th grade students. Results indicated that adolescents who played computer games actually were better adjusted than those who did not. Game players were found to have higher levels of self-esteem, lower levels of substance use, to be more attached to and involved with school, and to have closer family relationships than those who did not play computer games. Little support for the premise that game playing is related to negative outcomes was found. Although the Durkin and Barber study made an important contribution to the literature, the data are dated (data collection took place in 1988) and only computer game use was examined (video games and other types of media were not assessed). This is a critical limitation because the type of media available and adolescents' use of media are changing at a rapid pace. Therefore, a goal of the present study was to extend the Durkin and Barber study to adolescents today and to examine the relations between various types of media and adolescent adjustment.

Recent work also suggests that media use may serve as a protective factor for troubled youth. In a community sample of 14-16 year-olds, boys who spent relatively more time playing video games and watching television reported the lowest levels of anxiety (Ohannessian, 2009). This pattern was especially pronounced in boys with an alcoholic parent. Perhaps certain types of media (e.g., video games, watching television) provide adolescents with a means to psychologically disengage from their problems. This type of disengagement may be psychologically adaptive according to coping and motivational theories (e.g., Klinger, 1975).

In sum, most research to date has focused on the negative effects that media use may have on adolescent adjustment. Moreover, most studies have examined negative indicators of adjustment (e.g., psychological problems, substance use). The present study adopted a more optimistic outlook by assessing positive indicators of adjustment. It also is important to note that the majority of research examining associations between media use and adolescent adjustment to date has been cross-sectional or has examined only one direction of effect, that is whether media use influences adolescent adjustment. However, according to developmental systems theoretical models of human development (Lerner, et al., 2011; Overton, 2010), characteristics of the individual and the context influence one another in order to produce development. As such, the goal of this study was to examine bidirectional relations between media use and positive adjustment (as indicated by self-competence) in a large, diverse 
community sample of adolescents. More specifically, the following research questions were addressed:

1) Does media use predict adolescent self-competence? and/or

2) 2) Does adolescent self-competence predict media use?

\section{Method}

\section{Participants}

The sample included $1,03110^{\text {th }}$ and $11^{\text {th }}$ grade students ( $53 \%$ female) from the MidAtlantic region of the United States (Delaware, Maryland, and Pennsylvania). During the spring of 2007 (Time 1) and the spring of 2008 (Time 2), students completed surveys in school. The mean age of the adolescents was $16.15(\mathrm{SD}=.75)$. Most $(58 \%)$ of the adolescents were Caucasian. However, 23\% were African-American, 12\% were Hispanic, and 2\% were Asian (the rest responded "other"). These percentages reflect the area from which the sample was drawn (71\% Caucasian, 23\% African American, 4\% Asian, 7\% Hispanic; U.S. Census Bureau, 2008). Most of the adolescents (72\%) lived with both of their biological parents $(96 \%$ of the adolescents lived with their biological mother, $73 \%$ lived with their biological father). In addition, the majority of mothers (96\%) and fathers (95\%) were high school graduates. Some of the parents ( $26 \%$ of mothers and $24 \%$ of fathers) had graduated from a four-year college. A minority of the parents (10\% of mothers and $7 \%$ of fathers) had attended graduate school.

\section{Procedure}

Of note, the study protocol was approved by the University of Delaware's Institutional Review Board. Seven U.S. public high schools located within approximately 60 miles of the study site participated. In the spring of $2007,10^{\text {th }}$ and $11^{\text {th }}$ grade students from these high schools, who provided assent and had parental consent, were administered a survey in school by trained research personnel (all of whom were certified with human subjects training). Seventy-one percent of the students attending the study schools participated. Most of the students that did not participate were absent on the day of data collection. Only three percent of the adolescents present during data collection did not participate.

The adolescents were told that participation was voluntary, that the data collected were confidential, and that they could withdraw from the study at any time. They also were informed that a Certificate of Confidentiality from the U.S. government would further protect their privacy. The survey took approximately 40 minutes to complete. At the completion of the survey, the adolescents were given a movie pass. All participating adolescents were invited to participate again the following spring (Time 2). The same protocol was used at Time 2.

\section{Measures}

The survey included a demographic questionnaire. This questionnaire included questions relating to the age of the adolescent and their parents' highest education level completed $(1=$ elementary school to $6=$ graduate or medical school). The survey also included measures of media use and self-competence.

Media Use. The adolescents were asked how much time they spent talking on the phone, listening to music (radio), text messaging, e-mailing/IMing, playing video games (PlayStation, Nintendo, Game Boy, Xbox, etc.), using an iPod/MP3 player, and working on the computer "on an average/typical day." The response scale was $1=$ none, $2=$ less than one hour, $3=$ about one hour, $4=$ about 2 hours, $5=$ about three hours, and $6=4$ or more hours. 
Self-Competence. The participants also completed the Self-Perception Profile for Adolescents (SPPA; Harter, 1988), which included the following five-item scales: Selfperceived social competence, scholastic competence, athletic competence, and physical appearance. The response scale for the SPPA is presented in a four-point structured alternative format that translates to $1=$ low perceived competence to $4=$ high perceived competence. Prior research has supported the validity of the SPPA (Harter, 1988). In the present sample, Cronbach alpha coefficients ranged from .77 to .88 .

\section{Results}

\section{Bivariate Analyses}

Pearson product-moment correlations for the study variables are presented in Table 1. As shown, social competence was positively associated with talking on the phone, text messaging, listening to music, and e-mailing/IMing, and negatively associated with playing video games. In contrast, academic competence was negatively related to text messaging and athletic competence was positively related to playing video games. Physical appearance was positively related to talking on the phone; however, it was unrelated to all of the other types of media use assessed. 
Table 1

Means, Standard Deviations, and Correlations between the Study Variables

\begin{tabular}{|c|c|c|c|c|c|c|c|c|c|c|c|}
\hline Variable & 1 & 2 & 3 & 4 & 5 & 6 & 7 & 8 & 9 & 10 & 11 \\
\hline 1. Social Competence & - & $.33 * * *$ & $.37 * * *$ & $.43 * * *$ & $.19 * * *$ & $.11^{* *}$ & $.20 * * *$ & .02 & $-.10 *$ & .06 & -.06 \\
\hline 2. Scholastic Competence & $.34 * * *$ & - & $.25^{* * *}$ & $.34 * * *$ & -.07 & $-.11 * *$ & $-.09 *$ & -.03 & -.04 & .00 & $.08 *$ \\
\hline 3. Athletic Competence & $.27 * * *$ & $.15 * * *$ & - & $.33 * * *$ & -.01 & -.01 & .03 & -.03 & $.12^{* *}$ & -.01 & -.02 \\
\hline 4. Physical Appearance & $.35^{* * *}$ & $.3 * * *$ & $.28 * * *$ & - & $.09 *$ & -.01 & .00 & -.07 & -.05 & -.02 & .01 \\
\hline 5. Talking on the phone & .08 & $-.10 *$ & -.02 & .04 & - & $.44 * * *$ & $.41 * * *$ & $.26 * * *$ & .00 & $.29 * * *$ & $.23 * * *$ \\
\hline 6. Listening to Music & .05 & $-.11 *$ & -.05 & -.01 & $.35 * * *$ & - & $.31 * * *$ & $.30 * * *$ & $.09 * *$ & $.43 * * *$ & $.23 * * *$ \\
\hline 7. Text Messaging & $.14 * *$ & $-.09 *$ & -.03 & -.06 & $.34 * * *$ & $.26 * * *$ & - & $.32 * * *$ & -.02 & $.24 * * *$ & $.16 * * *$ \\
\hline 8. E-Mailing/IMing & $.09 *$ & -.08 & -.01 & -.06 & $.27 * * *$ & $.24 * * *$ & $.40 * * *$ & - & $.16^{* * *}$ & $.28 * * *$ & $.45^{* * *}$ \\
\hline 9. Playing Video Games & $-.10^{*}$ & -.03 & $.14 * * *$ & .00 & .00 & .02 & .03 & $.08^{*}$ & - & $.27 * * *$ & $.26 * * *$ \\
\hline 10. Using iPod/MP3 & $.12 * *$ & -.02 & $.09 *$ & .04 & $.24 * * *$ & $.20 * * *$ & $.29 * * *$ & $.31 * * *$ & $.14 * * *$ & - & $.35 * * *$ \\
\hline 11. Working on Computer & -.02 & -.01 & -.02 & -.02 & $.22 * * *$ & $.19 * * *$ & $.21 * * *$ & $.47 * * *$ & $.18^{* * *}$ & $.33 * * *$ & - \\
\hline Mean & 16.09 & 15.14 & 13.52 & 14.12 & 3.40 & 4.00 & 2052 & 3.02 & 2.46 & 3.13 & 3.19 \\
\hline SD & 2.99 & 3.24 & 3.94 & 3.94 & 1.55 & 1.55 & 1.70 & 1.71 & 1.62 & 1.75 & 1.58 \\
\hline \multicolumn{12}{|c|}{$\begin{array}{l}\text { Note: Correlations between the media use measures at Time } 1 \text { and the self-competence measures at Time } 2 \text { are presented under the diagonal. } \\
\text { Correlations between the self-competence measures at Time } 1 \text { and the media use measures at Time } 2 \text { are presented above the diagonal. } \\
\text { Means and SDs are from Time } 1 .{ }^{*} p<.05 ;{ }^{* *} p<.01 ;{ }^{* * *} p<.001 \text {. }\end{array}$} \\
\hline
\end{tabular}

\section{Longitudinal Analyses}

Path analysis was employed to examine whether media use (at Time 1) predicted selfcompetence one year later (Time 2) and/or whether self-competence (at Time 1) predicted media use one year later (Time 2). The endogenous variables assessed at Time 1, adolescent age, and parental education were included as covariates. Full information maximum likelihood (FIML) was used to handle missing data. FIML utilizes all available data (the covariance matrix and a vector of the means) to produce maximum likelihood-based sufficient statistics. Notably, FIML has been observed to yield unbiased parameter estimates (Wothke, 2000).

\section{Multiple Group Analyses}

Multiple group comparison analyses were conducted to determine whether separate analyses should be conducted for boys and girls. Consistent with the recommendations of Vandenberg 
and Lance (2000) for testing invariance across groups, for each direction of effect, an unconstrained model with freely estimated parameters was compared to a model constraining path coefficients to be equal for boys and girls. The $x^{2}$ difference test comparing the constrained model to the unconstrained model was not significant for either direction $\left(\Delta x^{2}(7)=8.35, p=.30\right.$ when self-competence was predicted from media use, and $\Delta X^{2}(16)=$ $23.21, p=.11$ when media use was predicted from self-competence). These results indicated that for both directions of effect, the constrained model did not provide a worse fit to the data than the unconstrained model. Therefore, the subsequent models were not conducted separately by gender.

\section{Does Media Use Predict Adolescent Self-Competence?}

The model predicting self-competence from media use provided a good fit to the data $\left(X^{2}(96)\right.$ $=286.10, p=.00 ; \mathrm{CMIN} / \mathrm{DF}=2.98 ; \mathrm{CFI}=.94 ; \mathrm{RMSEA}=.04)$. However, only two paths were significant (see Figure 1 ). As shown in Figure 1, listening to music frequently predicted lower perceived athletic competence $(\beta=-.05, p<.05)$, whereas playing video games frequently predicted higher perceived athletic competence $(\beta=.07, p<.01)$.

\section{Figure 1}

Model predicting self-competence from technology use. Standardized regression coefficients are presented. Only significant paths are shown. Control variables, covariances, and error terms are not displayed. $* p .05 ; * * p<.01 ; * * * p<.001$.

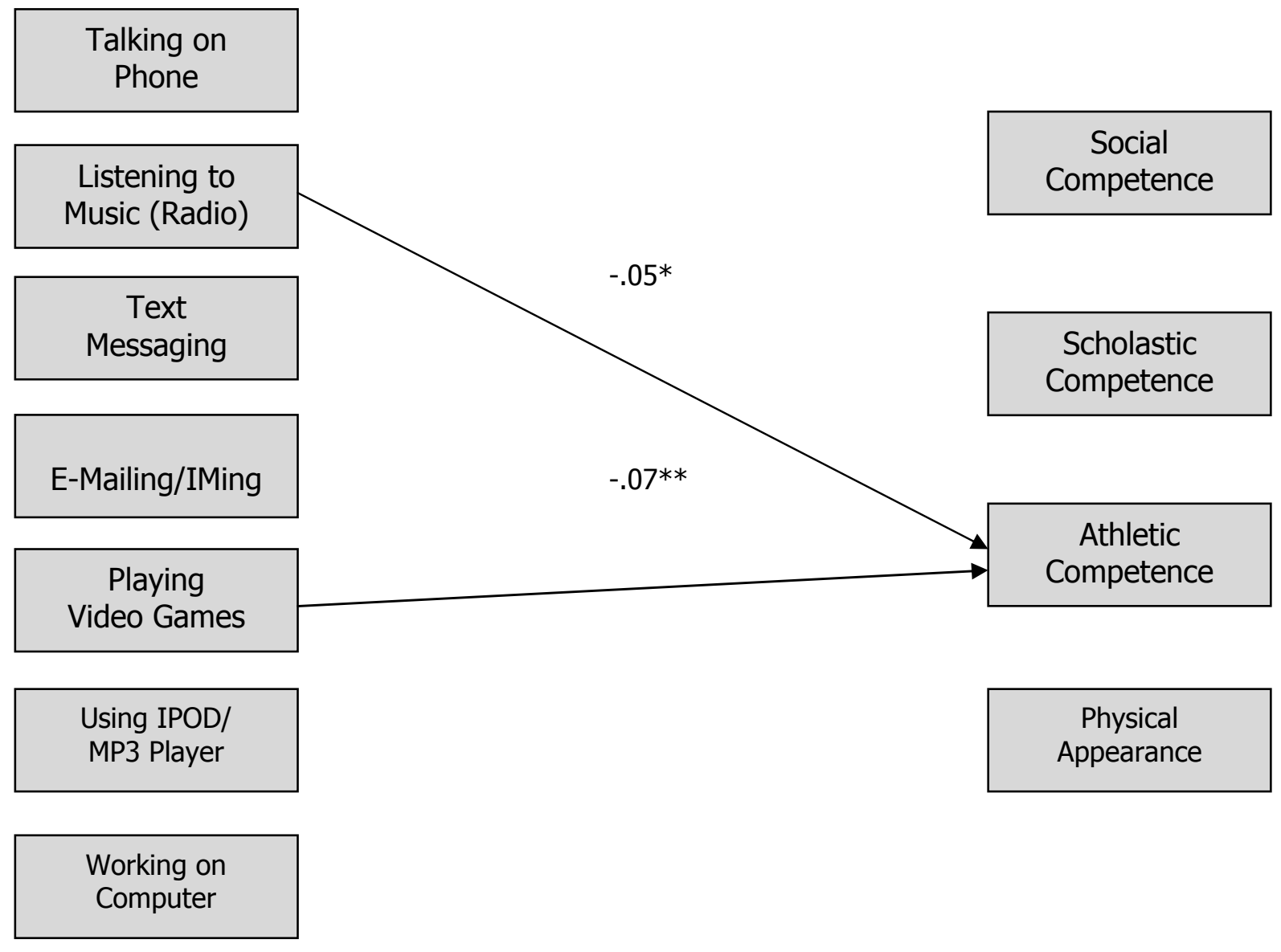




\section{Does Adolescent Self-Competence Predict Media Use?}

The model predicting media use from self-competence also fit the data well $\left(X^{2}(126)=\right.$ $420.16, p=.00 ; \mathrm{CMIN} / \mathrm{DF}=3.34 ; \mathrm{CFI}=.92 ; \mathrm{RMSEA}=.05)$. In contrast to the previous model, self-competence consistently predicted media use (see Figure 2 ). More specifically, higher perceived athletic competence predicted more frequent video game playing ( $\beta=.09$, $p<.01)$. In addition, higher perceived social competence predicted more frequent phone use $(\beta=.14, p<.001)$, more frequent listening to music on the radio $(\beta=.11, p<.01)$, and more frequent text messaging $(\beta=.18, p<.001)$. In contrast, higher perceived scholastic competence predicted less frequent phone use $(\beta=-.08, p<.05)$, less frequent listening to music on the radio $(\beta=-.11, p<.01)$, less frequent text messaging $(\beta=-.13, p<.001)$, and more frequent computer use $(\beta=.09, p<.05)$.

\section{Figure 2}

Model predicting technology use from self-competence. Standardized regression coefficients are presented. Only significant paths are shown. Control variables, covariances, and error terms are not displayed. $* p<.05 ; * * p<.01 ; * * * p<.001$.

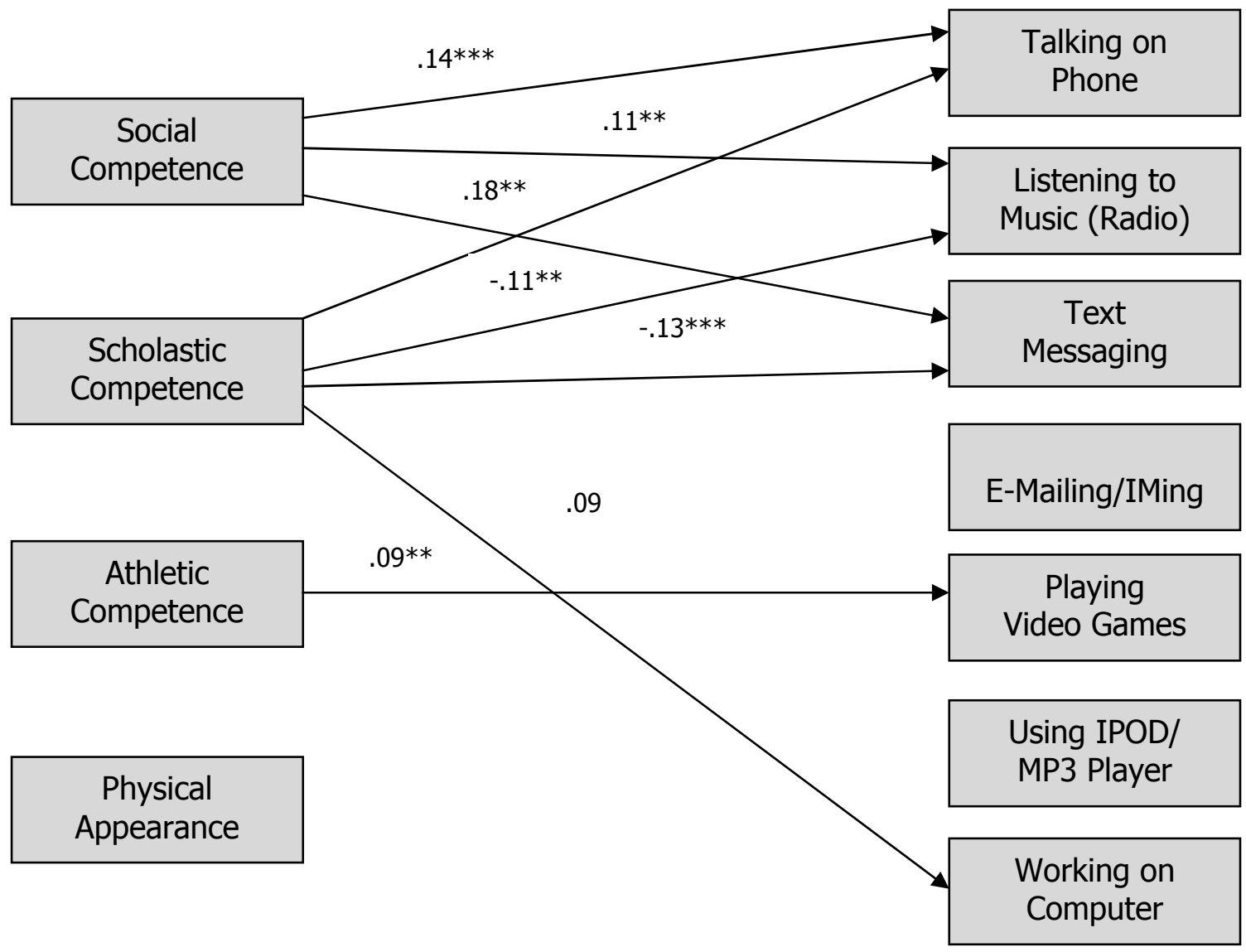

\section{Discussion}

The majority of research conducted on adolescent media use to date has focused on negative aspects of media use. However, consistent with the work of Durkin and Barber (2002) and Ohannessian (2009), results from this study suggest that media use also may be associated with positive adolescent adjustment. In the present study, more frequent phone use (talking and texting), listening to music, and e-mailing/IMing were associated with higher levels of 
social competence. More frequent video game playing similarly was linked to higher levels of athletic competence. Not surprisingly, more frequent computer use was related to higher levels of scholastic competence. These results are encouraging given that adolescents now are spending so much time interacting with media (an average of 7.5 hours a day; Rideout, et al., 2010).

Although many positive associations between media use and adolescent adjustment were found in this study, a few negative associations also were observed. More specifically, more frequent video game playing was related to lower levels of social competence and more frequent texting was associated with lower levels of scholastic competence. It is interesting to note that the pattern of results in this study were dependent on the indicator of selfcompetence. For example, the frequent use of social types of media (talking on the phone, texting, e-mailing) was linked to higher levels of social competence. In contrast, the frequent use of social media was related to lower levels of academic competence. Taken together, these findings underscore the importance of considering both negative and positive effects of media use on adolescent adjustment and the need to examine multiple indicators of adjustment.

A primary goal of this study was to examine the direction of effect between media use and adolescent self-competence. The longitudinal results suggest that although media use may influence adolescents' athletic competence (e.g., more frequent video game playing predicted more athletic competence over time), media use does not appear to influence how adolescents feel about themselves academically, socially, or in regard to their appearance. However, the findings do indicate that how adolescents feel about themselves academically, socially, and athletically influences their media use. These findings are important because they demonstrate different patterns of results depending on the direction of effect examined. The extant literature on adolescent media use has focused on the influence that media use has on adolescent adjustment. However, results from this study indicate that the influence that adolescent adjustment may have on media use should not be overlooked.

The results from this study suggest that socially well-adjusted youth may be relatively more likely to use media. These findings mirror results from a recent study examining social networking in youth (Mikami, Szwedo, Allen, Evans, \& Hare, 2010). In their study, Mikami and colleagues found that better adjusted youth (as indicated by more positive peer relations and fewer depressive symptoms) were more likely to have a social networking page than less well-adjusted youth. Importantly, the present study extends these findings beyond online social communication. In the present study, more socially adjusted youth similarly reported more frequent social media use such as talking and texting on the phone. Of note, these findings are consistent with and extend the "rich-get-richer" hypothesis, which suggests that Internet use (e.g., Facebook) is most beneficial for youth with strong social skills (Valkenburg, \& Peter, 2011).

Although the present study clearly contributes to the literature by examining the direction of effect between media use and adolescent adjustment in a large diverse sample, caveats should be noted. Adolescents provided the reports of their media use and self-competence. However, it is important to note that research has shown that youth are accurate reporters of their own behaviors (Dekovic, et al., 2006). Nonetheless, it would be informative for future research to replicate the findings from this study using other types of methodology (e.g., parent reports). Also, of note, the present study focused on the entire range of media use. Different findings might have emerged if only high end users of media (e.g., those who may 
be "addicted" to playing video games or to other types of media) were included. It also should be noted that the research project was designed in 2006 and data for this study were collected in 2007 and 2008. At that time, social network sites such as Facebook were not commonly used by high school students (Lerer, 2007). As such, social networking was not included in the current study. Finally, it should be noted that the sample only included adolescents from the Mid-Atlantic United States. Therefore, caution should be taken in regard to generalizing the findings.

Notwithstanding, results from this study are important because they indicate that media use reflects adolescent behavior in a contemporary context. That is, there appears to be continuity in adolescent media and non-media behavior. For instance, youth who have high levels of social competence are likely to behave socially with or without the use of media. Prior research has shown that social competence is linked to social behavior and having positive friendships during adolescence (Keefe, \& Berndt, 1995). In this study, more socially competent youth talked on the phone more, e-mailed more, and texted more frequently than less socially competent youth. These findings suggest that media use essentially is a vehicle for adolescents to do what they would do otherwise. Simply put, media use appears to extend, but not alter, adolescent behavior.

\section{References}

Anderson, C.A., Gentile, D.A., \& Buckley, K.E. (2007). Violent video game effects on children and adolescents: Theory, research, and public policy. New York, NY: Oxford University Press.

Brown, J.D., \& Bobkowski, P.S. (2011). Older and newer media: Patterns of use and effects on adolescents' health and well-being. Journal of Research on Adolescence, 21(1), 95-113.

Dekovic, M., Ten Have, M., Vollebergh, W., Pels, T., Oosterwegel, A., Wissink, I.B., et al. (2006). The cross-cultural equivalence of parental rearing measure: EMBU-C. European Journal of Psychological Assessment, 22, 85-91.

Durkin, K., \& Barber, B. (2002). Not so doomed: Computer game play and positive adolescent development. Applied Developmental Psychology, 23(4), 373-392.

Gentile, D.A., Lynch, P.J., Linder, J.R., \& Walsh, D.A. (2004). The effects of violent video game habits on adolescent hostility, aggressive behaviors, and school performance. Journal of Adolescence, 27, 5-22.

Harter, S. (1988). Manual for the Self-Perception Profile for Adolescents. Denver, CO: University of Denver.

Keefe, K., \& Berndt, T.J. (1996). Relations of friendship quality to self-esteem in early adolescence. Journal of Early Adolescence, 16(1), 110-129.

Klinger, E. (1975). Consequences of commitment to and disengagement from incentives. Psychological Review, 82, 1-25.

Koezuka, N., Koo, M., Allison, K.R., Adlaf, E.M., Dwyer, J.J.M., Faulkner, G., \& Goodman, J. (2006). The relationship between sedentary activities and physical inactivity among adolescents: Results from the Canadian Community Health Survey. Journal of Adolescent Health, 39, 515522. 
Kraut, R., Patterson, M., Lundmark, V., Kiesler, S., Mukopadhyay, T., \& Scherlis, W. (1998). Internet paradox: A social media that reduces social involvement and psychological well-being? American Psychologist, 53, 1017-1031.

Lerer, L. (2007). "Why MySpace Doesn't Card." Forbes (New York). http://classicweb.archive.org/web/20080602081817/http://www.forbes.com/security/2007/0 1/25/myspace-security-identity-tech-security-cx_II_0124myspaceage.html.

Lerner, R.M., Lerner, J.V., Lewin-Bizan, S., Bowers, E.P., Boyd, M.J., Mueller, M.K., et al. (2011). Positive Youth Development: Processes, programs, and problematics. Journal of Youth Development, 6(3), 40-64.

Marshall, S.J., Biddle, S.J., Gorely, T., Cameron, N., \& Murdey, I. (2004). Relationships between media use, body fatness and physical activity in children and youth: A metaanalysis. International Journal of Obesity, 28, 1238-1246.

Mikami, A.Y., Szwedo, D.W., Allen, J.P., Evans, M.A., \& Hare, A.L. (2010). Adolescent peer relationships and behavior problems predict young adults' communication on social networking websites. Developmental Psychology, 46(1), 46-56.

Ohannessian, C.M. (2009). Does technology use moderate the relationship between parental alcoholism and adolescent alcohol and cigarette use? Addictive Behaviors, 34, 606-609.

Overton, W.F. (2010). Life-span development: Concepts and issues. In R.M. Lerner \& W.F. Overton (Eds.), The handbook of life-span development: Vol. 1. Cognition, biology, and methods (pp. 1-29). Hoboken, NJ: Wiley.

Rideout, V., Foehr, U.G., \& Roberts, D.F. (2010). Generation M2: Media in the lives of 8-18 year-olds. Menlo Park, CA: The Henry J. Kaiser Family Foundation.

U.S. Census Bureau. (2008). U.S. Census Bureau: State and county QuickFacts. Retrieved May 16, 2010, from http://quickfacts.census.gov/qfd/states/10/10003.html.

Valkenburg, P.M., \& Peter, J. (2011). Online communication among adolescents: An integrated model of its attraction, opportunities, and risks. Journal of Adolescent Health, 48, 121-127.

Vandenberg, R.J., \& Lance, C.E. (2000). A review and synthesis of the measurement invariance literature: Suggestions, practices, and recommendations for organizational research. Organizational Research Methods, 3(1), 4-70.

(C) Copyright of Journal of Youth Development $~$ Bridging Research and Practice. Content may not be copied or emailed to multiple sites or posted to a listserv without copyright holder's express written permission. Contact Editor at: patricia.dawson@oregonstate.edu for details. However, users may print, download or email articles for individual use.

ISSN 2325-4009 (Print); ISSN 2325-4017 (Online) 


\section{MEDIA USE QUESTIONNAIRE}

We would like for you to tell us how much you use technology.

Please indicate how much time you spend doing each activity on an average/typical day by circling the appropriate number.

For each activity, please circle one of the following:

$$
\begin{aligned}
& 1=\text { None } \\
& 2=\text { Less than } 1 \text { hour } \\
& 3=\text { About } 1 \text { hour } \\
& 4=\text { About } 2 \text { hours } \\
& 5=\text { About } 3 \text { hours } \\
& 6=4 \text { or more hours }
\end{aligned}
$$

\begin{tabular}{|c|c|c|c|c|c|c|}
\hline & None & $\begin{array}{l}\text { Less } \\
\text { Than } \\
1 \text { Hour }\end{array}$ & $\begin{array}{l}\text { About } \\
1 \text { Hour }\end{array}$ & $\begin{array}{l}\text { About } \\
2 \\
\text { Hours }\end{array}$ & $\begin{array}{l}\text { About } \\
3 \text { Hours }\end{array}$ & $\begin{array}{l}4 \text { or } \\
\text { More } \\
\text { Hours }\end{array}$ \\
\hline 1. Watch T.V. & 1 & 2 & 3 & 4 & 5 & 6 \\
\hline 2. Talk on the phone & 1 & 2 & 3 & 4 & 5 & 6 \\
\hline $\begin{array}{l}\text { 3. Listen to music on a } \\
\text { stereo or radio }\end{array}$ & 1 & 2 & 3 & 4 & 5 & 6 \\
\hline 4. Text message & 1 & 2 & 3 & 4 & 5 & 6 \\
\hline 5. E-mail or IM & 1 & 2 & 3 & 4 & 5 & 6 \\
\hline $\begin{array}{l}\text { 6. Play video games } \\
\text { (PlayStation, Nintendo, } \\
\text { Game Boy, Xbox, etc.) } \\
\text { or computer games }\end{array}$ & 1 & 2 & 3 & 4 & 5 & 6 \\
\hline $\begin{array}{l}\text { 7. Listen to an IPOD or } \\
\text { MP3 player }\end{array}$ & 1 & 2 & 3 & 4 & 5 & 6 \\
\hline 8. Work on the computer & 1 & 2 & 3 & 4 & 5 & 6 \\
\hline 9. Surf the Web & 1 & 2 & 3 & 4 & 5 & 6 \\
\hline
\end{tabular}




\section{Self-Competence Survey}

\section{Directions:}

First, we would like you to decide whether you are more like the teenagers on the left side who would rather go to the movies, or whether you are more like the teenagers on the right side who would rather go to sporting events. Don't mark anything down yet, but first decide which kind of teenager is most like you, and go to that side of the page. Now, decide whether that is only sort of true for you or really true for you and mark your answer box with an "X".

\section{Be sure to only check one of the four boxes for each pair of sentences!}

\section{Sample Sentence}

\begin{tabular}{|c|c|c|l|l|l|c|c|}
\hline & $\begin{array}{c}\text { Really } \\
\text { True } \\
\text { for Me }\end{array}$ & $\begin{array}{c}\text { Sort of } \\
\text { True } \\
\text { for Me }\end{array}$ & $\begin{array}{l}\text { Some teenagers like to go } \\
\text { to the movies in their } \\
\text { spare time }\end{array}$ & $\square$ & & $\begin{array}{c}\text { Other teenagers would rather } \\
\text { go to sporting events }\end{array}$ & $\begin{array}{c}\text { Sort of } \\
\text { True } \\
\text { for Me }\end{array}$ \\
$\begin{array}{c}\text { Really } \\
\text { True } \\
\text { for Me }\end{array}$ \\
$\square$
\end{tabular}

\begin{tabular}{|c|c|c|c|c|c|c|c|}
\hline & $\begin{array}{l}\text { Really } \\
\text { True } \\
\text { for Me }\end{array}$ & $\begin{array}{l}\text { Sort of } \\
\text { True } \\
\text { for Me }\end{array}$ & & BUT & & $\begin{array}{l}\text { Sort of } \\
\text { True } \\
\text { for Me }\end{array}$ & $\begin{array}{l}\text { Really } \\
\text { True } \\
\text { for Me }\end{array}$ \\
\hline 1. & $\square$ & ए & $\begin{array}{l}\text { Some teenagers feel that } \\
\text { they are just as smart as } \\
\text { others their age }\end{array}$ & BUT & $\begin{array}{l}\text { Other teenagers aren't so sure } \\
\text { and wonder if they are as } \\
\text { smart }\end{array}$ & & \\
\hline 2. & $\square$ & L & $\begin{array}{l}\text { Some teenagers find it } \\
\text { hard to make friends }\end{array}$ & BUT & $\begin{array}{l}\text { For other teenagers, it's pretty } \\
\text { easy }\end{array}$ & & \\
\hline 3. & $\square$ & $\square$ & $\begin{array}{l}\text { Some teenagers do very } \\
\text { well at all kinds of sports }\end{array}$ & BUT & $\begin{array}{l}\text { Other teenagers don't feel that } \\
\text { they are very good when it } \\
\text { comes to sports }\end{array}$ & & \\
\hline 4. & & & $\begin{array}{l}\text { Some teenagers are not } \\
\text { happy with the way they } \\
\text { look }\end{array}$ & BUT & $\begin{array}{l}\text { Other teenagers are happy } \\
\text { with the way they look }\end{array}$ & & \\
\hline 5. & & & $\begin{array}{l}\text { Some teenagers are often } \\
\text { disappointed with } \\
\text { themselves }\end{array}$ & BUT & $\begin{array}{l}\text { Other teenagers are pretty } \\
\text { pleased with themselves }\end{array}$ & & \\
\hline 6. & $\square$ & & $\begin{array}{l}\text { Some teenagers are pretty } \\
\text { slow in finishing their } \\
\text { school work }\end{array}$ & BUT & $\begin{array}{l}\text { Other teenagers can do their } \\
\text { school work more quickly }\end{array}$ & & \\
\hline 7. & & & $\begin{array}{l}\text { Some teenagers have a } \\
\text { lot of friends }\end{array}$ & BUT & $\begin{array}{l}\text { Other teenagers don't have } \\
\text { very many friends }\end{array}$ & & \\
\hline 8. & & & $\begin{array}{l}\text { Some teenagers think } \\
\text { they could do well at just } \\
\text { about any new athletic } \\
\text { activity }\end{array}$ & BUT & $\begin{array}{l}\text { Other teenagers are afraid } \\
\text { they might not do well at a } \\
\text { new athletic activity }\end{array}$ & & \\
\hline 9. & & & $\begin{array}{l}\text { Some teenagers wish their } \\
\text { body was different }\end{array}$ & BUT & $\begin{array}{l}\text { Other teenagers like their body } \\
\text { the way it is }\end{array}$ & & \\
\hline 10. & & & $\begin{array}{l}\text { Some teenagers don't like } \\
\text { the way they are leading } \\
\text { their life }\end{array}$ & BUT & $\begin{array}{l}\text { Other teenagers do like the } \\
\text { way they are leading their life }\end{array}$ & & \\
\hline 11. & & & $\begin{array}{l}\text { Some teenagers do very } \\
\text { well at their classwork }\end{array}$ & BUT & $\begin{array}{l}\text { Other teenagers don't do very } \\
\text { well at their classwork }\end{array}$ & & \\
\hline 12. & $\square$ & $\square$ & $\begin{array}{l}\text { Some teenagers are very } \\
\text { hard to like }\end{array}$ & BUT & $\begin{array}{l}\text { Other teenagers are really } \\
\text { easy to like }\end{array}$ & & $\square$ \\
\hline 13. & $\square$ & $\square$ & $\begin{array}{l}\text { Some teenagers feel that } \\
\text { they are better than } \\
\text { others their age at sports }\end{array}$ & BUT & $\begin{array}{l}\text { Other teenagers don't feel } \\
\text { they can play as well }\end{array}$ & $\square$ & $\square$ \\
\hline
\end{tabular}




\begin{tabular}{|l|c|c|l|l|l|c|c|}
\hline & $\begin{array}{c}\text { Really } \\
\text { True } \\
\text { for Me }\end{array}$ & $\begin{array}{c}\text { Sort of } \\
\text { True } \\
\text { for Me }\end{array}$ & & & & $\begin{array}{c}\text { Sort of } \\
\text { True } \\
\text { for Me }\end{array}$ & $\begin{array}{c}\text { Really } \\
\text { True } \\
\text { for Me }\end{array}$ \\
\hline 14. & $\square$ & $\square$ & $\begin{array}{l}\text { Some teenagers wish their } \\
\text { physical appearance was } \\
\text { different }\end{array}$ & BUT & $\begin{array}{l}\text { Other teenagers like their } \\
\text { physical appearance the way it } \\
\text { is }\end{array}$ & $\square$ & $\square$ \\
\hline 15. & $\square$ & $\square$ & $\begin{array}{l}\text { Some teenagers are } \\
\text { happy with themselves } \\
\text { most of the time }\end{array}$ & BUT & $\begin{array}{l}\text { For other teenagers are often } \\
\text { not happy with themselves }\end{array}$ & $\square$ & $\square$ \\
\hline 16. & $\square$ & $\square$ & $\begin{array}{l}\text { Some teenagers have } \\
\text { trouble figuring out the } \\
\text { answers in school }\end{array}$ & BUT & $\begin{array}{l}\text { Other teenagers almost always } \\
\text { can figure out the answers }\end{array}$ & $\square$ & $\square$ \\
\hline 17. & $\square$ & $\square$ & $\begin{array}{l}\text { Some teenagers are } \\
\text { popular with others their } \\
\text { age }\end{array}$ & BUT & $\begin{array}{l}\text { Other teenagers are not very } \\
\text { popular }\end{array}$ & $\square$ & $\square$ \\
\hline 18. & $\square$ & $\square$ & $\begin{array}{l}\text { Some teenagers don't do } \\
\text { very well at new outdoor } \\
\text { games }\end{array}$ & BUT & $\begin{array}{l}\text { Other teenagers are good at } \\
\text { new games right away }\end{array}$ & $\square$ & $\square$ \\
\hline 19. & $\square$ & $\square$ & $\begin{array}{l}\text { Some teenagers think that } \\
\text { they are good looking }\end{array}$ & BUT & $\begin{array}{l}\text { Other teenagers think that } \\
\text { they are not very good looking }\end{array}$ & $\square$ & $\square$ \\
\hline 20. & $\square$ & $\square$ & $\begin{array}{l}\text { Some teenagers like the } \\
\text { kind of person they are }\end{array}$ & BUT & $\begin{array}{l}\text { Other teenagers often wish } \\
\text { they were someone else }\end{array}$ & $\square$ & $\square$ \\
\hline 21. & $\square$ & $\square$ & $\begin{array}{l}\text { Some teenagers feel that } \\
\text { they are pretty intelligent }\end{array}$ & BUT & $\begin{array}{l}\text { Other teenagers question } \\
\text { whether they are intelligent }\end{array}$ & $\square$ & $\square$ \\
\hline 22. & $\square$ & $\square$ & $\begin{array}{l}\text { Some teenagers feel that } \\
\text { they are socially accepted }\end{array}$ & BUT & $\begin{array}{l}\text { Other teenagers wished that } \\
\text { more people they age } \\
\text { accepted them }\end{array}$ & $\square$ & $\square$ \\
\hline 23. & $\square$ & $\square$ & $\begin{array}{l}\text { Some teenagers do not } \\
\text { feel that they are very } \\
\text { athletic }\end{array}$ & BUT & $\begin{array}{l}\text { Other teenagers feel that they } \\
\text { are very athletic }\end{array}$ & $\square$ & $\square$ \\
\hline 25. & $\square$ & $\square$ & $\begin{array}{l}\text { Some teenagers really like } \\
\text { the way they look }\end{array}$ & $\begin{array}{l}\text { Some teenagers are very } \\
\text { happy being the way they } \\
\text { are }\end{array}$ & BUT & $\begin{array}{l}\text { Other teenagers wish they } \\
\text { looked different }\end{array}$ & $\begin{array}{l}\text { Other teenagers wish they } \\
\text { were different }\end{array}$ \\
\hline
\end{tabular}

